\title{
"Benign" shaken baby syndrome. Case report
}

\author{
J.F. Martínez-Lage*; J. Ros de San Pedro; A. Puche** and M.A. Pérez-Espejo*
}

Servicio Regional de Neurocirugía. **Sección de Neuropediatria Hospital Universitario "Virgen de la Arrixaca". Murcia. *Laboratorio de Neurología y Neurocirugía Experimental (Grupo NYNE). Facultad de Medicina. Universidad de Murcia

\section{Summary}

The authors report an infant with clinical and neuroimaging findings of shaken baby syndrome. The pitfalls encountered in the assessment on the cause of the bilateral frontal and interhemispheric subdural hematomas in this child are also briefly discussed. We have called this condition "benign" shaken baby syndrome and emphasize that not always acute subdural hematomas are of non-accidental nature.

KEY WORDS: Acute subdural intracranial hematoma. Shaken baby syndrome. Child abuse. Non-accidental pediatric head injury. Heimlich maneuver.

\section{Síndrome "benigno" del niño sacudido}

\section{Resumen}

Los autores describen un lactante con hallazgos clínicos y de neuroimagen sugestivos del síndrome del niño maltratado. Se discuten brevemente las dificultades para la identificación de la causa del hematoma subdural agudo frontal bilateral e interhemisférico que el niño presentaba. Hemos denominado a esta entidad síndrome "benigno" del niño maltratado para destacar que el hallazgo de un hematoma subdural agudo en un niño pequeño no significa necesariamente maltrato infantil.

PALABRAS CLAVE: Hematoma subdural intracraneal agudo. Síndrome del niño maltratado. Síndrome del niño sacudido. Traumatismo infantil no accidental. Maniobra de Heimlich.

\section{Introduction}

Heimlich maneuver is a method devised for clearing up the obstructed airways and is used for choking or drow-

Recibido: 19-09-05. Aceptado: 29-09-05 ning. The procedure has several variations according to the patients' age. Although well-known, Heimlich maneuver is seldom carried out adequately due to lack of training for most non-professional personnel. The method can save many human lives but when applied inappropriately is also apt to cause unwanted harmful effects.

Inflicted injuries account for almost a quarter of all hospital admissions for infantile head trauma in the United States ${ }^{4}$. These lesions are associated with high rates of morbidity and mortality ${ }^{5,7-11}$. Several authors have remarked the difficulties met for the diagnosis of the shaking-impact syndrome particularly when there are no other signs of abuse, but just an uncorroborated accident, frequently a fall ${ }^{11}$. Some authors have pointed out the possibility of child abuse being overdiagnosed in certain countries while in others it might be missed ${ }^{1,6,11}$. Although the occurrence of inflicted injury is well known by pediatricians in Spain, there are no reliable data on the true incidence of these injuries in our mean. The diagnosis of child abuse must be established on a constellation of facts, among which a dependable clinical history is essential $^{3,11}$.

The authors report a child who sustained subdural and retinal hemorrhages during Heimlich maneuver to emphasize the fact that this association is not always related to non-accidental injury.

\section{Case report}

A 3.55 -months-old baby was admitted to the pediatric intensive care unit after having experienced an acute episode of loss of consciousness. The parents referred that the child became choked during food intake. The infant vomited, got a congested face followed by cyanosis, and became unconscious. During transport to an emergency department, the father applied the Heimlich maneuver, shaking the baby forcefully. At the Emergency Service cardiopulmonary resuscitation was instituted and the patient was transferred to our hospital. On admission, the child was pale and hypotonic and had a Glasgow coma score of 11 together with a full anterior fontanel. After a 


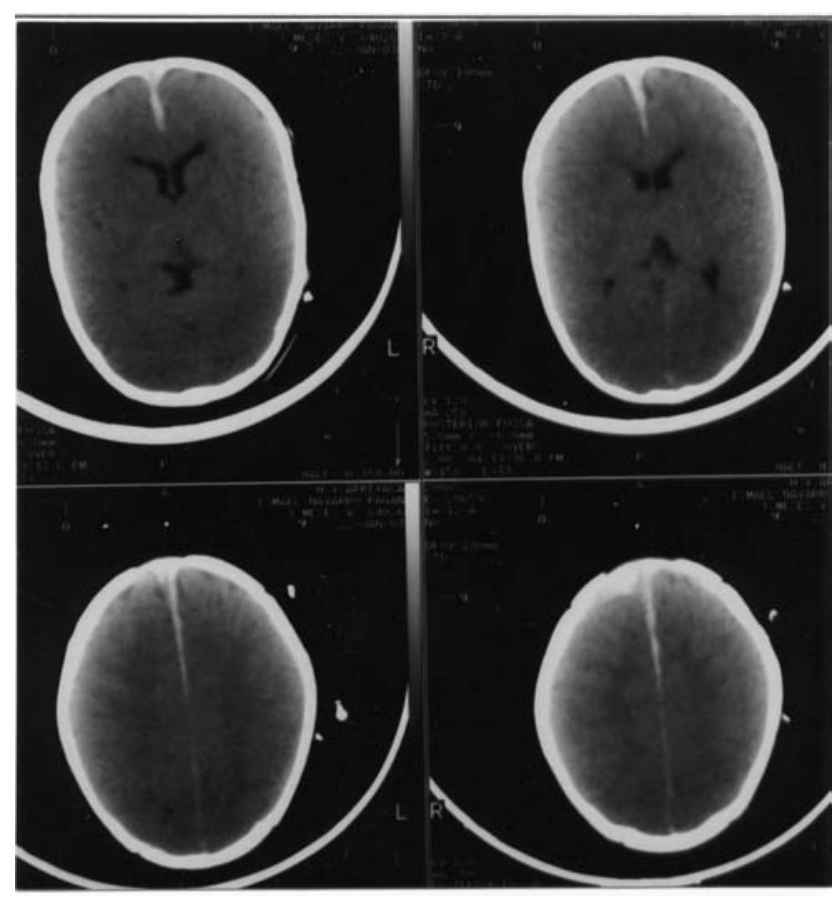

Figure 1. Initial CT showing an interhemispheric acute subdural hematoma.

few minutes the child had almost completely recovered but showed poor reactivity and did not pursue with his eyes. There were no external marks of trauma.

Laboratory investigations demonstrated a low hemoglobin and hematocrit count, and normal values of blood gases, electrolytes and coagulation tests. A computerized tomography (CT) head scan showed an acute bifrontal and interhemispheric hemorrhage, and ruled out the presence of brain ischemia or contusions (Fig. 1). A lumbar puncture demonstrated hemorrhagic cerebrospinal fluid. Ophthalmologic examination discovered vitreous and retinal hemorrhages. An EEG was reported as normal. A repeat CT showed partial resolution of the supratentorial subdural hemorrhage and images of subarachnoid hemorrhage along the tentorium and the surface of both cerebellar hemispheres. A skeletal survey ruled out the presence of fractures.

The child was managed conservatively and showed a steady improvement until his hospital discharge, 2 weeks after admission. At the last follow-up visit, at 13 months of age, the child appeared slightly retarded for his age and had a squint. EEG was normal. Evoked visual potentials were mildly impaired on the right and normal on the left.

Magnetic resonance imaging showed relatively enlarged pericerebral spaces.

\section{Discussion}

In recent years there has been a great concern on the subject of child abuse $e^{2-5,8-11}$. Clinical, neuroimaging and neuropathologic features of inflicted head injury have been amply publicized in current literature and will not be dealt with in our discussion $2,3,5,8-11$.

A main diagnostic clue is the presence of an unsustainable clinical history ${ }^{11}$. There are cases in which the diagnosis can be established with little or no doubt ${ }^{8,11}$. These include: (a) confession of intentional injury by a caretaker, (b) inadequate or inconsistent history -the history given does not justify the severity of the injuries, (c) associated unexplained lesions as fractures or abdominal trauma, and (d) delay in seeking care ${ }^{8}$.

In the study of Jenny et $\mathrm{al}^{8}$ of 173 cases of child abuse, inflicted head injuries comprised subdural hematoma $(86.7 \%)$, diffuse parenchymal brain injury $(44.5 \%)$, localized cerebral lesions $(37 \%)$, skull fracture $(31.8 \%)$ and epidural hemorrhage $(2.3 \%)$. The association of subdural hematomas and retinal hemorrhages is considered as almost pathognomonic of inflicted head injury ${ }^{8}$. In these authors' work the emphasis is placed on those cases that are initially missed or unrecognized ${ }^{8}$. On the other hand, there have been some differences of opinion about the diagnosis of abusive head trauma. Japanese authors support that child abuse is overdiagnosed, while American investigators suggest that many cases may go undetected ${ }^{1,6,11}$.

In our patient, the pediatricians suspected to be facing a case of abusive head injury, while the social and forensic investigations supported the accidental nature of this child's injuries. We have denominated this type of injury as "benign shaken baby syndrome" to refer to the unintentional mechanism of the injury rather than to the severity of the cerebral damage.

\section{Conclusions}

Abusive head trauma is a dangerous form of child abuse that entails high morbidity and mortality rates ${ }^{4}$. Reporting suspicious cases to social and judicial authorities may aid to prevent the reiteration of these injuries ${ }^{11}$. The role of the neurosurgeon, apart from providing professional care, consists of participating in the multidisciplinary hospital's team that manage child-abuse cases. However, some instances of seemingly inflicted head injury may result from true accidental events, as occurred in the case we report.

\section{Acknowledgements}

The authors are grateful for the expert collaboration of Mr. Saturnino Espín, photographer of the Hospital. 


\section{References}

1. Aoki, N., Masuzawa, H.: Infantile acute subdural hematoma: report of six cases from Japan. Neurosurgery 1986; 18 : 475-477.

2. Chen, C.Y., Zimmerman, R.A., Rorke, L.B.: Neuroimaging in child abuse: a mechanism based approach. Neuroradiology 1999; 41: 711-722.

3. Duhaime, A.C., Christian, C.W., Rorke, L.B., Zimmerman, A.R.: Nonaccidental head injury in infants - The "shaken baby syndrome". New Engl J Med 1998; 338:1822-1829.

4. Duhaime, A.C., Christian, C., Moss, E., Seidl, T.: Longterm outcome in infants with the shaking-impact syndrome. Pediatr Neurosurg 1996; 24: 292-298.

5. Geddes, J.F., Hackshaw, A.K., Vowles, G.H., Nickols, C.D., Whitwell, H.L.: Neuropathology of inflicted head injury in children. I. Patterns of brain damage. Brain 2001; 124 : 1290-1298.

6. Gutierrez, F.A., Raimondi A.J.: Acute subdural hematoma in infancy and childhood. Child's Brain 1975; 1:269290.
7. Jennet, B: The epidemiology of head injury. Arch Dis Child 1998; 78: 403-406.

8. Jenny, C., Hymel, K.P., Ritzen, A., Reinert, S.E., Hay, T.C. : Analysis of missed cases of abusive head trauma. JAMA 1999; 281: 621-626.

9. Lonergan, G.J., Baker, A.M., Morey, M.K., Boos, S.C.: From the archives of the AFIP. Child abuse: radiologic-pathologic correlation. Radiographics 2003; 23: 811-845.

10. Vinchon, M., Defoort-Dhellemmes, S., Desurmont, M., Dhellemmes P. : Accidental and nonaccidental head injuries in infants: a prospective study. J Neurosurg 2005; (Pediatrics 4) $102: 380-384$.

11. Wilkins, B.: Head injury — abuse or accident? Arch Dis Child 1997; 76: 393-397.

Martínez-Lage, J.F.; Ros de San Pedro, J.; Puche, A.; Pérez-Espejo, M.A.: "Benign" shaken baby syndrome. Neurocirugía 2006; 17: 348-350.

Correspondencia postal: Juan F. Martínez-Lage. Hospital Universitario "Virgen de la Arrixaca". El Palmar. E-30120 Murcia. 